\title{
DAMPAK PERNIKAHAN USIA DINI DI WILAYAH PEDESAAN A SYSTEMATIC REVIEW
}

\author{
Siti Ma'rifah, Toha Muhaimin \\ Fakultas Kesehatan Masyarakat, Universitas Indonesia, Depok, Indonesia \\ rifa11rifa@gmail.com
}

\begin{abstract}
Abstrak
Pernikahan dini memiliki implikasi yang serius pada kesehatan masyarakat. Secara global, lebih dari 650 juta wanita hidup atau satu dari lima gadis menikah sebelum 18 tahun, satu dari 20 anak perempuan menikah sebelum 15 tahun setiap harinya. Tujuan penelitian ini untuk mengetahui dampak pernikahan dini bagi perempuan dan populasi yang rentan terhadapnya. Tinjauan sistematis dilakukan pada database online SCOPUS, PubMed, ProQuest, dan EBSCO dengan lima kata kunci, "early marriage" OR "child marriage" AND "impact" OR "outcomes" AND "in rural areas" kemudian disaring berdasarkan publikasi khusus tahun 2012-2018, berbahasa Inggris, dan teks lengkap. Terdapat tujuh artikel asli memenuhi kriteria inklusi. Penelitian ini mengidentifikasi bahwa pernikahan dini meningkatkan kemungkinan kehamilan yang tidak diinginkan, terminasi kehamilan, kelahiran mati, keguguran, komplikasi kehamilan atau persalinan, kesuburan tinggi, kekurangan gizi, kesehatan mental, mendapat kekerasan pasangan intim, sulit dalam kegiatan sehari-hari. Akibatnya, mereka memiliki kemungkinan untuk lebih sering dan lebih awal hamil, yang dimana ini menimbulkan berbagai keluhan kesehatan baik jangka pendek bahkan jangka panjang, dalam beberapa kasus dapat mengakibatkan kematian. Kesimpulannya, terdapat banyak dampak dalam pernikahan dini. Sehingga, mencegah terjadinya pernikahan dini merupakan hal terpenting yang harus dilakukan, yaitu memberikan pendidikan seksualitas, kesehatan reproduksi, dan dampak pernikahan usia dini secara komprehensif.
\end{abstract}

Kata kunci: Pernikahan Dini, Kesehatan Wanita, IPV, Daerah Pedesaan,

\section{Pendahuluan}

Pernikahan dini, didefinisikan oleh UNICEF (2018) sebagai perkawinan formal atau tidak formal sebelum usia 18 tahun. Secara global, lebih dari 650 juta wanita yang hidup hari ini menikah sebelum usia 18 tahun. Diperkirakan bahwa 12 juta anak perempuan di bawah 18 tahun menikah setiap tahun. Secara keseluruhan, proporsi wanita yang menikah sebagai anak menurun 15 persen dalam dekade terakhir, satu dari empat menjadi sekitar satu dari lima pada saat ini, dan lebih dari 150 juta anak perempuan tambahan akan menikah sebelum ulang tahun ke 18 mereka pada tahun 2030 (UNICEF, 2018). Pernikahan anak perempuan yang paling umum adalah di Afrika dan Asia. yaitu antara 50\% dan $60 \%$ di seluruh Sub Sahara Afrika. Negaranegara dengan jumlah pernikahan anak mutlak tertinggi adalah India (15.509.000), Bangladesh (4.451.000), Nigeria (3.538.000) (GNB, 2018). Indonesia termasuk di antara 10 negara (ke 8) dengan jumlah perkawinan anak absolut tertinggi: 1.408 .000 perempuan berusia 20 hingga 24 tahun menikah sebelum usia 18 tahun (GNB, 2018). 
Pernikahan dini telah memberi dampak besar bagi anak perempuan dan anak-anak mereka. Dan itu tidak hanya diakui sebagai pelanggaran manusia, namun juga merupakan penghalang bagi perkembangan individu dan sosial. Banyak bukti menunjukkan bahwa efek negatifnya banyak, terutama berbahaya bagi anak perempuan, anak-anak mereka, komunitas mereka, dan juga menciptakan siklus antargenerasi yang merugikan (Groot et al. 2018).

Pernikahan dini biasanya dilakukan para gadis-gadis yang hidup dalam status sosial ekonomi rendah, yang memiliki pendidikan kurang secara formal, dan yang tinggal di daerah pedesaan (Kamal SMM, 2012). Untuk penentu lain dari pernikahan dini adalah kurangnya hukum, budaya, konflik dan kerentanan (Efevbera et al. 2017, Hotchkiss et al. 2016). Oleh karena itu, penting untuk memahami efek pernikahan dini mengenai status ekonomi mereka, pendidikan, dan kota asal mereka, terutama di daerah pedesaan.

\section{Bahan dan Metode}

Untuk melaporkan temuan-temuan menggunakan desain sistematik review dengan mengikuti Panduan Pilihan untuk Ulasan Sytematic Review dan Meta Analyses (PRISMA) dan menggunakan flowchart berdasarkan daftar periksa PRISMA 2009, yaitu dengan menghilangkan artikel yang tidak relevan dengan menggunakan kriteria inklusi, penyaringan, kelayakan, dan pengunduhan akhir artikel yang relevan (Moher et al, 2009).

Strategi Pencarian: Artikel-artikel yang dicari di database secara online (PubMed, SCOPUS, ProQuest, EBSCO) untuk studi yang dikaji oleh rekan sejawat dan menilai hasil dari perkawinan anak di daerah pedesaan. Langkah pertama adalah membuka lib.ui.ac.id, membuka koleksi dan memilih database secara online, dan membuka setiap basis data satu per satu. Dengan menggunakan mesin telusur dengan kata kunci "early marriage" OR "child marriage" AND "impact" OR "outcomes" AND "in rural areas" melalui jurnal PubMed, EBSCO, SCOPUS, dan ProQuest. Dan dipilih berdasarkan publikasi tertentu (6 tahun), Bahasa Inggris, teks lengkap, dan memilih jurnal berdasarkan relevansi, penilaian kelayakan. Kriteria inklusi dokumen yang dianggap tepat (kelayakannya) untuk melakukan sistematik review adalah sebagai berikut: jurnal dari penelitian, dilaporkan dalam bahasa Inggris, diterbitkan 6 tahun terakhir (dari 1 Januari 2012 hingga 31 Desember 2018). Kriteria inklusi untuk responden adalah anak perempuan yang telah menikah, dampak / hasil untuk kesehatan, studi desain dicampur. Kriteria eksklusi adalah sebagai berikut: desain uji klinis; menggunakan bahasa kecuali bahasa Inggris dan Bahasa Indonesia, artikel yang diterbitkan kurang dari 2012, dampak nonkesehatan. Ekstraksi dan analisis data dari setiap artikel yang dilakukan oleh penulis. Hasilnya dianalisis dan data disusun sesuai dengan analisis tema dan disusun dalam bentuk kertas narasi 

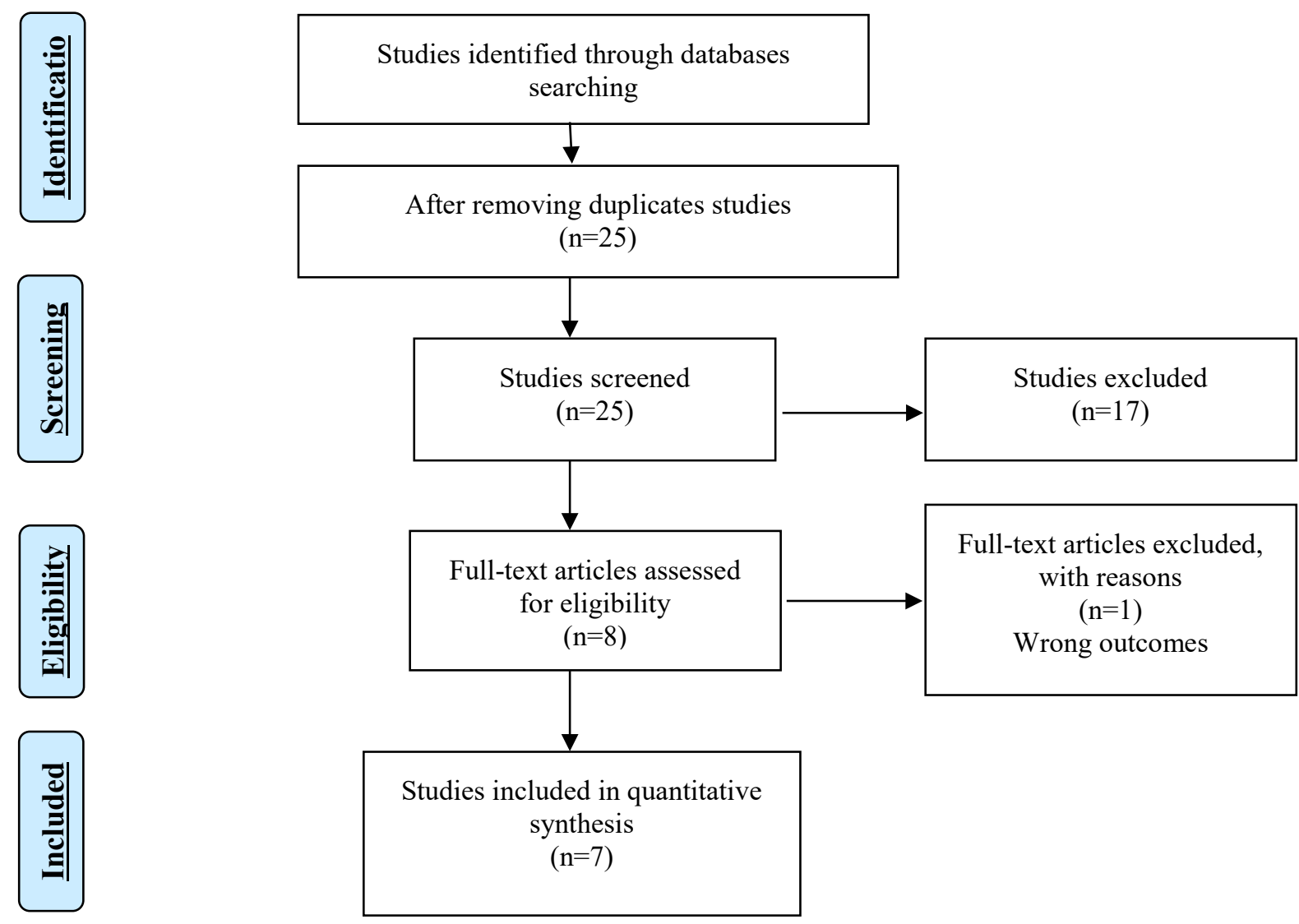

Gambar 1. Item Pelaporan Terpilih untuk PRISMA

PICOS: Populasi yang diteliti dalam penelitian ini adalah wanita yang menikah $<18$ tahun. Intervensi dalam ulasan ini mendapat dampak kesehatan pernikahan dini. Komparator tinjauan ini memiliki dampak kesehatan atau tidak. Hasil dari tinjauan ini mencegah pernikahan anak. Desain penelitian yang dipilih oleh penulis adalah cross-sectional dan longitudinal penelitian ini dilakukan dalam tiga fase: mencari dan mengumpulkan literatur dan data dengan mencari strategi dan memilih studi dalam basis data jurnal online, menganalisis dan mengevaluasi literatur dan data yang ditemukan dengan menilai kualitas penelitian menggunakan penilaian kritis yang sesuai dengan desain artikel, mengkategorikan dan meringkas literatur dan data. (Proses seleksi dengan menggunakan diagram alur disajikan pada Gambar 1 


\section{Tabel 1. Ringkasan deskriptif karakteristik penelitian}

\begin{tabular}{|c|c|c|c|c|c|c|c|}
\hline No & $\begin{array}{l}\text { Authors, year } \\
\text { Published }\end{array}$ & Location & $\begin{array}{l}\text { Study } \\
\text { Design }\end{array}$ & $\begin{array}{l}\text { Sample } \\
\text { Size } \\
\end{array}$ & Age & Dampak & Statistik \\
\hline 1 & $\begin{array}{l}\text { Groot et al. } \\
2018\end{array}$ & Ghana & $\begin{array}{l}\text { Cross } \\
\text { Sectional }\end{array}$ & 1.349 & $20-29$ & $\begin{array}{l}\text { Kesulitan dalam } \\
\text { kegiatan sehari-hari } \\
\text { Kematian anak di } \\
\text { antara anak-anak } \\
\text { sulung }\end{array}$ & $\begin{array}{l}\text { PUD dalam sampel ini dikaitkan } \\
\text { dengan peningkatan kemungkinan } \\
\text { kesehatan yang lebih buruk, diukur } \\
\text { dengan kesulitan dalam kegiatan } \\
\text { sehari-hari (OR 2,08, 95\% CI 1,28- } \\
3,38 \text { di antara wanita } 20-24 \text { tahun dan } \\
\text { OR } 1,58,95 \% \text { CI } 1,19-2,12 \text { di antara } \\
\text { wanita } 20-29 \text { tahun), peningkatan } \\
\text { kemungkinan kematian anak di antara } \\
\text { anak-anak pertama (OR } 2.03,95 \% \text { CI } \\
\begin{array}{l}1.09-3.77 \text { di antara wanita } 20-24 \\
\text { tahun) }\end{array}\end{array}$ \\
\hline 2 & $\begin{array}{l}\text { Kamal SMM. } \\
2012\end{array}$ & Bangladesh & $\begin{array}{l}\text { Cross } \\
\text { Sectional }\end{array}$ & 9.572 & $20-49$ & $\begin{array}{l}\text { Kecil kemungkinan } \\
\text { dalam penggunaan } \\
\text { metode kontrasepsi } \\
\text { sebelum persalinan; } \\
\text { lebih mungkin } \\
\text { memiliki tiga atau } \\
\text { lebih anak; } \\
\text { kehamilan tidak } \\
\text { diinginkan; aborsi }\end{array}$ & $\begin{array}{l}\text { Pernikahan dini secara bermakna lebih } \\
\text { mungkin memiliki tiga atau lebih anak } \\
\text { (OR 3,94, 95\% CI 3,38-4,58), } \\
\text { peningkatan risiko kehamilan yang } \\
\text { tidak diinginkan (OR } 1,2195 \% \text { CI } \\
1,02-1,45) \text { meningkatkan risiko } \\
\text { penghentian kehamilan (OR 1,16,95 } \\
\% \text { CI 1.00-1.34) dibandingkan dengan } \\
\text { wanita yang menikah sebagai orang } \\
\text { dewasa. }\end{array}$ \\
\hline 3 & $\begin{array}{l}\text { Nasrullah et al. } \\
2013\end{array}$ & Pakistan & $\begin{array}{l}\text { Cross } \\
\text { Sectional }\end{array}$ & 1.560 & $20-24$ & $\begin{array}{l}\text { Secara signifikan } \\
\text { terkait dengan } \\
\text { ferltility yang tinggi } \\
\text {; Pengulangan cepat } \\
\text { Kehamilan tidak } \\
\text { diinginkan } \\
\text { Pengakhiran } \\
\text { kehamilan }\end{array}$ & $\begin{array}{l}\text { Pernikahan dini secara bermakna } \\
\text { dikaitkan dengan tingkat kesabaran } \\
\text { yang tinggi (OR 6.62, 95\% CI 3.53- } \\
12.43 \text { ) kelahiran berulang cepat (OR } \\
2.8895 \% \text { CI } 1.74-4.75) \text { kehamilan } \\
\text { yang tidak diinginkan (OR } 2.90,95 \% \\
\text { CI } 1.75-4.79) \text { dan penghentian } \\
\text { kehamilan (OR } 1,75,95 \% \text { CI } 1,10- \\
2,78)\end{array}$ \\
\hline 4 & $\begin{array}{l}\text { Sekine et al. } \\
2014\end{array}$ & Nepal & $\begin{array}{l}\text { Cross } \\
\text { sectional }\end{array}$ & 14.162 & $15-49$ & $\begin{array}{l}10 \text { kali lebih } \\
\text { mungkin putus } \\
\text { sekolah }\end{array}$ & $\begin{array}{l}\text { Pernikahan dini secara signifikan lebih } \\
\text { cenderung meninggalkan sekolah (OR } \\
10,04,95 \% \text { CI } 5,84-17,25)\end{array}$ \\
\hline 5 & $\begin{array}{l}\text { Adedoku et al. } \\
2016\end{array}$ & Nigeria & $\begin{array}{l}\text { Cross } \\
\text { sectional }\end{array}$ & 4013 & $15-45$ & $\begin{array}{l}\text { Komplikasi selama } \\
\text { kehamilan atau } \\
\text { persalinan } \\
\text { (pendarahan dan } \\
\text { anemia yang } \\
\text { berlebihan) } \\
\text { Persalinan macet / } \\
\text { berkepanjangan }\end{array}$ & $\begin{array}{l}\text { Sebagian besar }(91,9 \%) \text { dari } \\
\text { responden yang menikah telah hamil } \\
\text { sejak menikah dan dari mereka } \\
(54,4 \%) \text { telah mengalami komplikasi } \\
\text { selama kehamilan / persalinan yaitu } \\
\text { perdarahan yang berlebihan dan } \\
\text { anemia ( } 14 \% \text { dan } 13 \%) \text {, diikuti } 10 \% \\
\text { yang mengalami persalinan yang } \\
\text { terhambat atau berkepanjangan. }\end{array}$ \\
\hline 6 & $\begin{array}{l}\text { Goli et al. } \\
2015\end{array}$ & India & $\begin{array}{l}\text { Cross } \\
\text { Sectional }\end{array}$ & 124,385 & $15-49$ & Malnutrisi & $\begin{array}{l}\text { Gadis-gadis yang telah menikah dalam } \\
\text { kategori 'kurus' dalam sampel India } \\
(33 \% \text { p: } 0,001) \text { dan di negara yang } \\
\text { dipilih, Andhra Pradesh }(31 \% \text { p: } \\
0,001) \text { dan Bihar }(43 \% \text { p: } 0,001) \text {, } \\
\text { dibandingkan dengan mereka yang } \\
\text { menikah pada usia yang lebih tinggi. } \\
\text { Pengaruh usia pada pernikahan } \\
\text { pertama dan usia saat kelahiran } \\
\text { pertama pada status gizi adalah } \\
\text { signifikan. }\end{array}$ \\
\hline 7 & $\begin{array}{l}\text { Yount et al. } \\
2016\end{array}$ & $\begin{array}{l}\text { Rural } \\
\text { Bangladesh }\end{array}$ & $\begin{array}{l}\text { Longitudi } \\
\text { nal }\end{array}$ & 3.355 & $18-54$ & $\begin{array}{l}\text { mendapatkan } \\
\text { kekerasan dari } \\
\text { pasangan intim }\end{array}$ & $\begin{array}{l}\text { Hampir separuh }(44,5 \%) \text { perempuan } \\
\text { melaporkan IPV fisik, dan } 78 \% \text { telah } \\
\text { menikah sebelum usia } 18 \text { tahun }\end{array}$ \\
\hline
\end{tabular}




\section{Hasil}

Penelitian mengidentifikasi 7 studi untuk dimasukkan dalam analisis (Tabel 1). Ada 7 studi dari Bangladesh, India, Nepal, Ghana Utara, Nigeria, dan Pakistan. Untuk desain penelitian, semuanya menggunakan studi cross-sectional, dan hanya satu yang menggunakan longitudinal. Studi-studi menunjukkan ada banyak dampak kesehatan dari pernikahan dini.

Hasil dari studi cross-secional di Ghana menunjukkan bahwa sampel terdiri dari 1349 yang pernah menikah, mereka berusia 20-29 tahun dari 2497 rumah tangga di Ghana. Gadis-gadis yang telah menikah di usia dini dikaitkan dengan status kesehatan yang lebih buruk, yang diukur dengan kesulitan dalam kegiatan sehari-hari (OR $2,08,95 \%$ CI 1,28-3,38) di antara wanita 2024 tahun dan (OR 1,58, 95\% CI 1,19-2.12) di antara wanita 20-29 tahun, dan itu terkait dengan kematian anak di antara anak-anak yang lahir pertama (OR 2,03, 95\% CI 1,093,77 ) di antara wanita 20-24 tahun (Groot et al, 2018). Di Ghana, usia pernikahan yang sah adalah 18 tahun. Namun, mereka mendapat kelonggaran peraturan dan dapat menikah semuda 16 dengan izin orang tua mereka (GNB, 2018).

Di Bangladesh, ada aturan bahwa usia pernikahan pertama yang sah untuk pria dan wanita adalah 21 dan 18 tahun. Namun, berdasarkan penelitian ini dari 9,572 perempuan yang pernah menikah, hampir $63 \%$ menikah pada usia yang sangat muda, dan hampir $82 \%$ menikah pada usia kanakkanak. Hasil dari perkawinan anak secara signifikan lebih mungkin memiliki tiga atau lebih anak ATAU 3,94, 95\% CI 3,38-4,58), meningkatkan risiko kehamilan yang tidak diinginkan (OR 1,21, 95\% CI 1,02-1,45), meningkatkan risiko penghentian kehamilan (OR 1,16, 95\% CI 1,00-1,34) dibandingkan dengan wanita yang tidak melakukan pernikahan dini. Secara keseluruhan, prevalensi pernikahan dini adalah $82 \%$ (usia rata-rata menikah pertama adalah 15,3 tahun). Hal ini menunjukkan bahwa perempuan Bangladesh menikah pada 2,7 tahun lebih awal dari usia hukum pada pernikahan pertama untuk perempuan (Kamal SMM, 2012).

Penelitian dilakukan di Pakistan terdiri dari sampel oleh 1.560 wanita yang telah menikah, yang menunjukkan bahwa pernikahan dini secara bermakna dikaitkan dengan status ferltility tinggi (OR 6.62, 95\% CI 3.53-12.43), kelahiran berulang cepat (OR 2.88, 95\% CI 1.74-4.75), kehamilan yang tidak diinginkan (OR 2,90, 95\% CI $1,75-4,79$ ) dan terminasi kehamilan (OR $1,75,95 \%$ CI 1,10-2,78). Pernikahan dini secara signifikan berasosiasi dengan status kesuburan tinggi dan mereka memiliki kehamilan yang tidak diinginkan. (Nasrullah et al. 2013).

Penelitian dilakukan di Nepal dengan sampel sebesar 14.162 yang pernah menikahi seorang anak (15-17 tahun), menunjukkan bahwa gadis yang menikah secara signifikan lebih cenderung meninggalkan sekolah (OR 10.04, 95\% CI 5.84-17,25 ). Ini berarti bahwa gadis yang menikah di Nepal sepuluh kali lebih mungkin putus sekolah daripada mereka yang belum menikah. Karena ini menggarisbawahi, menunda pernikahan anak perempuan adalah untuk mengurangi putus sekolah anak perempuan di Nepal (Sekine dkk. 2017).

Penelitian ini dilakukan dengan studi cross sectional pada gadis-gadis muda di 21 sekolah menengah di tiga zona geopolitik di Plateau State, Nigeria. Sebagian besar responden yang menikah (46\%) mengatakan bahwa mereka dipaksa untuk melakukan pernikahan dini oleh orang tua mereka, diikuti oleh 20,3\% lainnya yang menikah karena mereka membutuhkan uang untuk pergi ke sekolah. Efek dari pernikahan dini anak perempuan adalah $68(91,9 \%)$ dari responden yang menikah telah hamil sejak menikah dan dari mereka $37(54,4 \%)$ telah mengalami komplikasi selama kehamilan atau persalinan yang sebagian besar adalah perdarahan yang berlebihan dan anemia (14\% dan 13\% masing-masing), diikuti oleh 
persalinan macet / berkepanjangan (10\%) (Adedokun et al. 2016). Dalam hal ini Konstitusi Nigeria tidak menentukan usia pernikahan minimum. Namun, di bawah Undang-Undang tentang Hak Anak, lulus pada tahun 2003 menetapkan usia pernikahan pada usia 18 (GNB, 2018).

Data dari putaran ketiga Survei Kesehatan Keluarga Nasional (NFHS) dilakukan di India selama 2005-2006. Survei ini mencakup sampel representatif dari 109.041 rumah tangga. Penelitian ini menunjukkan proporsi wanita yang lebih tinggi dalam kategori 'kurus' menikah sebelum 18 tahun, baik dalam sampel India (33\%, p: 0,001) dan di negara-negara yang dipilih, Andhra Pradesh (31\%, p: 0,001) dan Bihar (43\%, p: 0,001), dibandingkan dengan wanita yang menikah pada usia yang lebih tinggi. Demikian pula, di semua sampel yang kelahiran pertamanya sebelum usia 18 tahun memiliki kemungkinan lebih tinggi untuk berada dalam kategori "kurus" dan terkait dengan prematuritas dan anemia. Jadi itu akan menjadi masalah besar melalui siklus hidup (GNB, 2018).

Penelitian dilakukan di Pedesaan Bangladesh menggunakan data panel 20132014 pada 3,355 yang pernah menikah pada usia 15-17 tahun. Ini menunjukkan bahwa hampir separuh $(44,5 \%)$ perempuan melaporkan IPV fisik, dan $78 \%$ telah menikah sebelum berusia 18 tahun. Tingkat insiden IPv fisik di tingkat desa berkisar antara $11,4 \%$ hingga $75,0 \%$; usia perkawinan pertama rata-rata berkisar antara 14,8 hingga 18,0 tahun. Prevalensi tingkat desa rata-rata pernikahan anak usia dini berkisar antara 3,9\% hingga 51,9\%. Dalam efek utama dari menikah pada 18 atau lebih lama dilindungi terhadap IPV fisik, dan pernikahan anak dini yang lebih umum sebelum usia 15 adalah faktor risiko (Yount et al. 2016).

\section{Diskusi}

Pernikahan adalah peristiwa penting dalam siklus hidup seseorang dan landasan dalam proses pembentukan keluarga. Usia sangat menarik karena menandai transisi menuju kedewasaan di banyak masyarakat. Titik di mana opsi-opsi tertentu dalam pendidikan, pekerjaan, dan partisipasi dalam masyarakat disita, dan awal paparan risiko kehamilan dan persalinan.

Kebijakan usia minimum pernikahan di masing-masing negara bervariasi. Di Bangladesh dan India ada aturan bahwa usia pernikahan pertama untuk pria adalah 21 tahun dan wanita berusia 18 tahun. Dan pernikahan sah di Ghana untuk kedua anak perempuan dan anak laki-laki adalah 18 tahun. Namun, mereka dapat menikah semuda 16 dengan persetujuan dari orang tua mereka. Di Nigeria, berdasarkan undangundang tentang hak-hak anak yang diloloskan pada tahun 2003 menetapkan usia pernikahan adalah 18 tahun. Sementara itu, di India usia legal untuk menikah adalah 18 untuk wanita, 21 untuk pria. Meskipun ada aturan di setiap negara yang terkait dengan pernikahan, dalam penerapannya masih ada pernikahan di bawah 18 tahun. Dalam penelitian ini akan dipaparkan hasil 7 jurnal yang membahas tentang efek kesehatan dari pernikahan dini. Ini dapat digunakan sebagai informasi tambahan tentang kesehatan dan kesehatan masyarakat yang saat ini juga dialami di Indonesia.

Berdasarkan literatur studi, banyak penyebab pernikahan anak. Anak perempuan yang tinggal di daerah pedesaan lebih mungkin mengalami pernikahan anak daripada perkotaan, maka agama juga bisa menjadi penyebab pernikahan muda. Selain itu, pendidikan rendah juga bisa mengarah pada pernikahan dini. Penghentian kehamilan, pernikahan anak secara signifikan diasosiasikan dengan peningkatan kemungkinan jika setidaknya satu kali melahirkan, dan setidaknya satu kehamilan yang tidak diinginkan. (Nasrullah et al. 2013). Dalam banyak kasus, pernikahan dini adalah pendorong kehamilan dini, pernikahan mengikuti kehamilan yang sering terjadi pada wanita yang tidak diinginkan. Dalam beberapa kasus, gadis- 
gadis yang memiliki kehamilan yang tidak diinginkan akan memilih untuk mengakhiri kehamilan mereka. Dalam Penelitian oleh Kamal SMM (2012) di Bangladesh menunjukkan bahwa pernikahan dini secara signifikan meningkatkan kemungkinan kelahiran mati, keguguran, dan penghentian kehamilan. Anak-anak yang telah menikah memiliki risiko yang jauh lebih besar untuk memiliki bayi lahir mati dan kematian bayi baru lahir 50\% lebih tinggi pada mereka (GNB, 2018). Hal ini terkait dengan penelitian lain yang menjelaskan seks dini adalah umum pada anak-anak dan membawa pada komplikasi, ada persalinan lama hingga kelahiran anak yang sulit. Ada juga pada kehamilan awal yang dapat menyebabkan kematian dan morbiditas ibu. Dan kesimpulannya adalah gadis-gadis yang berusia 10-14 tahun lebih sering mengalami kehamilan atau melahirkan daripada wanita pada usia 20-24 tahun; dan juga mereka dua kali lebih mungkin mati (Biresaw, 2014).

Komplikasi selama kehamilan atau persalinan, anak-anak yang telah menikah memiliki risiko kematian dan morbiditas bayi perinatal yang jauh lebih besar. Yang disebabkan oleh tubuh mereka masih berkembang dan juga pengetahuan mereka tentang kesehatan seksual dan reproduksi sangat rendah. Baik secara fisik atau emosional siap melahirkan, mereka menghadapi risiko kematian yang lebih tinggi saat melahirkan dan sangat rentan terhadap kehamilan (GNB, 2018). Studi di Nigeria menjelaskan $54,4 \%$ responden menikah yang telah hamil mengalami komplikasi selama kehamilan atau persalinan, sebagian besar perdarahan yang berlebihan dan anemia diikuti oleh persalinan tertunda atau berkepanjangan, anemia telah dikaitkan dengan bukti kehamilan remaja. Temuan ini menunjukkan bahwa responden menghadapi risiko tinggi kematian terkait kehamilan yang merupakan penyebab utama kematian pada anak perempuan berusia 15-19 tahun di seluruh dunia (Adedokun et al. 2016). Penelitian sebelumnya telah menunjukkan bahwa responden telah mulai melahirkan anak-anak pada 14-18 tahun, 71\% telah mengalami setidaknya satu kehamilan yang serius / kelahiran terkait masalah kesehatan yang meliputi pendarahan yang berlebihan selama persalinan (19,0\%), persalinan tertunda / berkepanjangan $(49,0 \%)$, sering keguguran $(12,0 \%)$ dan penyakit setelah melahirkan (20\%). Selain itu, mereka yang telah mengalami berbagai komplikasi kesehatan, $26 \%$ telah terkena fistula vesiko-vaginal dan recto-vascinal dan berada dalam berbagai tahap pengobatan (Ea et al. 2016).

Kesuburan tinggi, pernikahan dini dikaitkan dengan melahirkan dalam banyak kasus, di negara berkembang di mana tujuan utama pernikahan adalah memiliki anak. Di Bangladesh, perempuan terburu-buru untuk melahirkan sedini mungkin untuk membuktikan kelangsingan mereka. Khususnya di daerah pedesaan, jika seorang wanita menunda kehamilannya, dia disalahkan bahwa dia tidak subur dan tidak mampu secara biologis untuk melahirkan anak. Maksudnya yang menikah lebih awal harus memiliki usia dini pada saat kelahiran pertama juga. Dalam penelitian lain mengatakan bahwa faktor budaya seperti keinginan suami untuk lebih banyak anak dan preferensi anak yang telah terbukti meningkatkan tingkat kesuburan dan penggunaan kontrasepsi yang rendah di kalangan wanita di Pakistan (Nasrullah et al. 2013) tampaknya meningkatkan risiko kesuburan dan rendahnya tingkat kesuburan. hasil kesuburan di antara istri anak.

Malnutrisi: hasilnya menunjukkan efek buruk yang besar dari perkawinan anak dan kelahiran dini pada status gizi wanita di India dan untuk negara bagian kami yang dipilih. Sebagian besar wanita yang menikah sebelum menikah pada usia pernikahan dan akibatnya terpapar pada kehamilan awal, ditemukan kurang gizi relatif terhadap wanita yang menikah di usia tua. Analisis juga menunjukkan bahwa dalam semua model kami, wanita menikah pada usia $\leq 25$ memiliki kemungkinan tertinggi untuk memiliki status gizi normal (Goli et al. 2015) 
Penelitian lain menunjukkan wanita hamil yang menikah sebelum usia mereka delapan belas tahun, berasal dari rumah tangga, tidak makanan yang aman, dan memiliki skor keragaman diet yang rendah hampir empat (OR 3,9, 95\% CI 2,2-6,9), dua (OR 2,3, 95\% CI 1,2-3,6), dan dua (ATAU 2,1, 95\% CI 1.3-4.16) lebih mungkin mengalami malnutrisi (Nigatu et al. 2018). Gadis yang menderita kekurangan gizi lebih mungkin memiliki anak dengan perkembangan akhir. Berdasarkan penelitian di Sub Sahara Afrika, mereka menemukan bahwa kemungkinan keluar dari jalan untuk pembangunan dan yang terhambat masingmasing 25\% dan 29\% lebih tinggi, untuk anak-anak yang lahir dari wanita yang sudah menikah sebelum berusia 18 tahun dibandingkan dengan mereka yang ibunya menikah kemudian $(\mathrm{p}<0,0010)$ (Efevbera et al. 2017).

Kesehatan mental (stres): normanorma di Ghana pada perempuan diharapkan mulai melahirkan anak-anak segera setelah menikah. Dalam hal ini pengantin anak cenderung tidak diberi pilihan untuk membuat keputusan. Temuan kami menunjukkan bahwa ada stres pada anakanak. Pernikahan anak dikaitkan dengan kesehatan mental yang lebih buruk, seperti bunuh diri, kurangnya harga diri dan depresi (Groot et al. 2018). Penelitian sebelumnya mengatakan Sekitar sepertiga wanita berusia 15-24 tahun di Pakistan melaporkan memiliki suami yang posesif dan perilaku kekerasan oleh suami mereka. Dibandingkan dengan pernikahan orang dewasa, pernikahan dini secara signifikan dikaitkan dengan perilaku posesif, pelecehan emosional, dan kekerasan fisik (Velotti et al. 2015).

Kekerasan pasangan intim (IPV): Pernikahan anak mengekspos perempuan ke IPV (kekerasan seksual, fisik, psikologis, emosional). Semakin besar perbedaan usia dengan suami, semakin besar kemungkinan mengalami kekerasan (50\% dan lebih). Usia pernikahan diasosiasikan dengan sebagian besar IPV. Di Bangladesh, hampir satu setengah $(44,5 \%)$ perempuan melaporkan insiden IPV fisik, dan 78,9\% telah menikah sebelum usia 18 tahun (Yount et al. 2016). Penelitian lain mendukung hubungan antara pernikahan dini dan IPV. Dalam penelitian lain, 22\% dari mereka yang menikah pada anak melaporkan pernah mengalami kekerasan fisik yang dilakukan oleh suami mereka, dibandingkan dengan $17 \%$ dari mereka yang menikah terlambat. Dan itu serupa untuk pengalaman kekerasan seksual (37\% vs 22\%) (Santhya et al. 2010).

Dalam kasus lain, gadis yang menikah dengan pria yang lebih tua yang telah memiliki pasangan seksual sebelumnya bisa sangat sulit bagi perempuan untuk menyatakan keinginan mereka, mereka memiliki kekuatan terbatas dalam menegosiasikan seks yang lebih aman. Dan situasi ini meningkatkan risiko seumur hidup infeksi HIV di antara pengantin anak Di Uganda, tingkat prevalensi HIV untuk gilrs 10-19 lebih tinggi untuk anak perempuan yang sudah menikah $(89 \%)$ daripada anak perempuan yang belum menikah (66\%) (GNB, 2018). Oleh karena itu, secara kolektif mengurangi perkawinan anak mungkin diperlukan untuk melindungi perempuan dari IPV dan HIV.

Sulit dalam Kegiatan sehari hari, pernikahan anak meningkat status kesehatan yang buruk, yang diukur dengan kesulitan dalam kegiatan sehari-hari. Dalam penelitian lain belum meneliti hubungan antara pernikahan anak dan ADL. Namun, temuan bahwa pernikahan anak secara signifikan lebih cenderung meninggalkan sekolah (10 kali lebih mungkin putus sekolah) (Sekine dkk. 2014).

Dalam upaya untuk membangun hubungan antara perkawinan dini dan hasilhasilnya yang terkait di daerah pedesaan dengan hanya menggunakan bukti ilmiah paling ketat yang tersedia, kami membatasi peninjauan sistematis terhadap artikelartikel yang diulas sejawat. sehingga laporan penelitian dan literatur abu-abu lainnya yang mungkin telah memeriksa hubungan antara perkawinan dini dan hasil ini, dan mungkin 


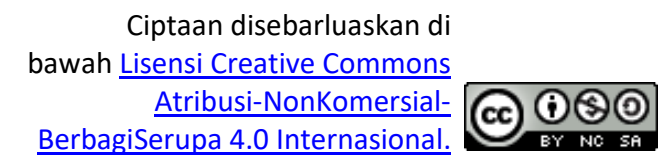

memberikan wawasan lebih lanjut, dikecualikan dari tinjauan kami. Dengan membatasi ulasan kami pada artikel yang diterbitkan dalam bahasa Inggris dan Indonesia, jadi mungkin telah melewatkan artikel tambahan.

Studi dari beberapa negara berpenghasilan tinggi dan di daerah pedesaan telah menunjukkan bahwa pernikahan dini dikaitkan dengan berbagai masalah terutama dalam masalah kesehatan baik wanita dan anak-anak. Kami menyimpulkan, ada banyak hasil dari itu sebagai meningkatkan kemungkinan kehamilan yang tidak diinginkan, terminasi kehamilan, kelahiran mati, keguguran, komplikasi selama kehamilan atau persalinan, kesuburan tinggi, kekurangan gizi, kesehatan mental (stres), mendapatkan kekerasan pasangan intim, dan sulit dalam aktivitas sehari-hari. Sehingga mencegah terjadinya pernikahan dini adalah hal yang paling penting.

\section{Kesimpulan}

Pernikahan dini adalah masalah besar karena memiliki dampak kesehatan yang besar. Kami menyimpulkan bahwa ada banyak hasil dari itu seperti meningkatkan kemungkinan kehamilan yang tidak diinginkan, terminasi kehamilan, lahir mati, keguguran, komplikasi selama kehamilan atau persalinan, kesuburan tinggi, kekurangan gizi, kesehatan mental (stres), mendapatkan kekerasan pasangan intim, dan sulit dalam kegiatan sehari-hari.

Mencegah terjadinya pernikahan dini adalah hal yang paling penting. Anak harus diberikan pendidikan yang terkait dengan hasil dari pernikahan dini. Juga, dapat dibuat peraturan untuk otoritas untuk menikah lebih dari 18 tahun. Pemerintah juga dapat memberikan bantuan untuk pendidikan dan memotivasi anak-anak untuk melanjutkan sekolah mereka untuk menunda usia pernikahan pada anak-anak. Anak-anak yang berhubungan dengan kesehatan harus diberikan makanan bergizi sesuai dengan kebutuhan mereka dan minum tablet besi untuk menghindari anemia yang juga mempengaruhi kehamilan di masa depan. Untuk penelitian masa depan dapat melanjutkan penelitian tentang hasil kesehatan dari pernikahan dini dengan metode penelitian lain dan negara lain.

\section{Referensi}

Adedokun OA, Gbemiga E, Adeyemi C D. (2016). Child Marraige and Maternal Health Risks among Young Mothers in Gombi, Adamawa State, Nigeria: Implications for Mortality, Entitlements and Freedoms. African Health Sciences, 16(12), 1-27

Biresaw, G. (2014). Implications of early marriage in Ethiopia. The Ahfad

Ea, E. Rj, U, et al. (2016). Determinants and effect of girl child marriage : a cross sectional study of school girls in Plateau State, Nigeria. International Journal of Medicine and Biomedical Research, 5(3).

Efevbera YB, Farmer PE, Fink G. (2017). Girl child marriage as a risk factor for early childhood development and stunting. Social Science \& Medicine.

GNB. (2018). Child Marriage around the world. access from: https://www.girlsnotbrides.org/wher e-does-it-happen/. Accessed on December 2018.

Goli S, Rammohan A, Singh D. (2015). The Effect of Early Marriages and Early Childbearing on Women' Nutritional Status in India. Maternal Child Health Journal, 1864-1880.

Groot RD, Kuunyem MY, Palermo T.(2018).Child marriage and associated outcomes in northern Ghana: a cross-sectional study. BMC Public Health, 1-12.

Hotchkiss DR, Godha D, Gage AJ, et al.(2016). Risk factors associated with the practice of Child Marriage among Roma Girls in Serbia Health Journal, 31(1), 79-86 
and Human Rights of Marginalized Populations. BMC International Health and Human Rights, 16(1), 110.

Kamal, SMM. (2012). Decline in Child Marriage and Changes in Its Effect on Reproductive Outcomes in Bangladesh. International Centre for Diarrhoeal Disease Research, Bangladesh. Health Popul Nutr. Sep; 30(3):317-330

Moher D, Liberati A, Tetzlaff J, et al. (2009). Preferred Reporting Items for Systematic Reviews and MetaAnalyses: The PRISMA statement. PloS Med. 2009; 6(7):e1000097.

Nasrullah M, Muazzam S, AZ, et al. (2013). Girl Child Marriage and its effect on Fertility in Pakistan: Finding from Pakistan Demographic and Health Survey, 2006-2007. Matern Child Health $J$ 18:534-543

Nigatu M, Gebrehiwot TT, \& Gemeda DH. (2018). Household Food Insecurity, Low Dietary Diversity, and Early Marriage Were Predictors for Undernutrition among Pregnant Women.

Parsons J, Edmeades J, Kes A, et al. (2015). Economic Impacts of Child Marriage: A Review of The Literature. The Review of Faith \& International Affairs.13(3):12-22

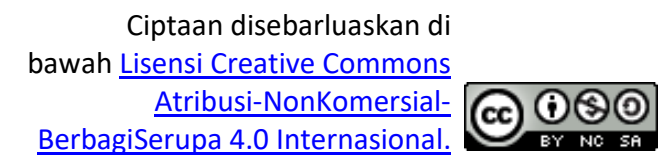

Santhya KG, Ram U, Acharya R, et al. (2010). Associations Between Early Marriage and Young Women's Marital and Reproductive Health Outcomes: Evidence from India. International Perspectives on Sexual and Reproductive Health, 36(3):132139

Sekine K, Hodgking ME.(2017). Effect of Child Marriage on girls' School dropout in Nepal: Analysis of Data from the Multiple Indicator Cluster Survey 2014. PloS ONE 12(7): $\mathrm{e} 0180176$

UNICEF. (2018). Child Marriage Among Girls. Avalibale on: https://data.unicef.org/topic/childprotection/child-marriage/. Accessed in December 2018.

Velotti P, Balzarotti S, Tagliabue S, et al. (2015). Emotional suppression in early marriage: Actor, partner, and similarity effects on marital quality. Journal of Social and Personal Relationships, 33(3), 277-302.

Yount KM, Crandall AA, Cheong YF, et al. (2016). Child Marriage and Intimate Partner Violence in Rural Bangladesh: A Longitudinal Multilevel Analysis. Journal of Demography 53:1821-1852 